\title{
Role of Knowledge Creation and Absorptive Capacity: A Panel Data Study of Innovation
}

\section{Kamran Hameed ${ }^{1}$, Noman Arshed (1) 2*, Mubbasher Munir ${ }^{3}$}

${ }^{1}$ Department of Management, University of Management and Technology, Lahore, Pakistan

2 Department of Economics, University of Management and Technology, Lahore, Pakistan

3 Department of Quantitative Methods, University of Management and Technology, Lahore, Pakistan

*Corresponding author: noman.arshed@umt.edu.pk

Article History

Received 2021-02-13

Revised 2021-03-07

Accepted 2021-03-11

Published 2021-03-12

Keywords

Absorptive capacity

Innovation

Knowledge acquisition

How to cite?

Hameed, K., Arshed, N., \& Munir, M. (2021). Role of Knowledge Creation and Absorptive Capacity: A Panel Data Study of Innovation. SEISENSE Journal of Management, 4(2), 2544. doi:

$10.33215 /$ sjom. $24 i 2.579$
Abstract

Purpose- Knowledge creation refers to the ability of firms to create new knowledge that starts from individuals to integrating the firms and then the overall economy. This study suggests that knowledge acquisition in a country has a significant relationship with innovative performance.

Design/Methodology- Data from 48 highly HDI countries is taken from World Bank and World Economic Forum. Based on 480 country-year observations in a panel mediator model, it is revealed that the national efforts of boosting knowledge acquisition influence the firms' innovative performance.

Findings- Further, it is found that absorptive capacity in the employability of knowledgeable workers works as a mediator between knowledge acquisition and innovation. Whereby higher knowledge acquisition leads to higher absorptive capacity and higher innovation.

Practical Implications- This study builds a quantitative model for the macroeconomic context of knowledge-based view. 


\section{Introduction}

In literature, various approaches have been used to address how firms can achieve sustainable competitive advantage. In the 1980s, the dominant paradigm in this field was proposed by (Porter, 1980) focusing on the five forces model. Later, one of the dominant approaches, 'Resource-based view' (RBV), emerged, discussing internal resources only as firm-level strategies are more prone to creating competitive advantage but less focused on rapid change in the external economic environment. In an extension in resource-based view, 'knowledgebased view' (KBV) of the firms considers as an emerging perspective that explains about achieving competitive advantage through knowledge-based assets, other than the conventional factor of production such as labor, capital, and land (Martín-de-Castro, Delgado-Verde, López-Sáez, \& Navas-López, 2011).

In the last two decades, studies within the field of management literature have focused on the importance of knowledge management in achieving innovative performance. Innovation (based on Solow residual) is considered one of the critical factors of economic growth (Solow, 1956). Highly human-developed countries are focusing on knowledge that is prorogated as a crucial determinant of innovation. A country's knowledge acquisition is a resource that works as a driving force to innovative performance (Molina-Morales, GarcíaVillaverde, \& Parra-Requena, 2014). New solutions to existing problems can be proposed through new knowledge accumulated in R\&D activities and absorbed into their skills and abilities (Zahra \& George, 2002). Innovation has established its position as an essential ingredient for firms' performance (Ramadani, Abazi-Alili, Dana, Rexhepi, \& Ibraimi, 2017) and long-term sustainable competitive advantage. The economic perspective has often cited innovation as a significant driver of economic growth and productivity (Freeman \& Soete, 1997). To address the question "how innovation can be improved," various disciplines have come in front in the literature to answer this question (Anderson \& West, 1996; Capon, Farley, Lehmann, \& Hulbert, 1992; Freeman \& Soete, 1997). Recently, the knowledge management field has emerged and has become critical approach to discuss innovation.

Novelty is created through innovation: "the development and adoption of new and improved ways of addressing social and economic needs and wants" (Kuhlmann, Shapira, \& Smits, 2010). Broadly, it covers business sophistication and R\&D innovation. Technological resources such as internet-wide accessibility (Song, Podoynitsyna, Van Der Bij, \& Halman, 2008; Wirtz, Schilke, \& Ullrich, 2010) and lack of barrier to entry have erupted as one of the significant challenges for established firms. Innovativeness determines firms' actions towards technological leadership, new product development, and change in the product. Innovation is an opportunity for highly developed human capital countries to stay competitive through knowledge acquisition in the current market environment. However, due to the ease of exchange of skilled workers around countries, it is a challenge to absorb through the hiring of these available, knowledgeable workers.

In the global marketplace, the winner firms do flexible innovation and timely respond to rapid environmental change coupled with internal and external knowledge resources management. Globalization, technological advancement, and other environmental factors direct firms to focus on closed innovation, which only focuses on internal research and development, to open innovation. This study covers both dimensions of open innovation: $\mathrm{R} \& \mathrm{D}$, collaboration with other institutes, and considerable attention by scholars $(\mathrm{H}$. Chesbrough, W. Vanhaverbeke, \& J. West, 2014; Randhawa, Wilden, \& Hohberger, 2016; Salampasis \& Mention, 2017).

Previous literature has yet to develop, revealing the direct empirical relationship between innovation and knowledge acquisition. Competition between firms works as a strategic driving force toward innovation. European Union used this idea by providing resources to various knowledge, skilled labor, and venture capital (Rutten \& Boekema, 2005). A country can achieve economic growth while executing this policy. However, innovation ingredients at the macro level are not well developed and measured. Firm-level theoretical perspectives are required to be seen at the macro level because firms are responsible for competing, which 
aggregates towards growth strategically. Kleiner (2011) justified the application of resource theory, under system paradigm, on micro and macro-economic systems

This paper will start from a theoretical discussion. Hypotheses are developed in the same section. Research design and results are presented in the following section. Lastly, the conclusion and discussion are presented along with limitations and future research direction of the study.

Knowledge management influences firms' strategies. However, knowledge acquisition or creation has both time and cost-saving advantages. Knowledge acquisition has a time-proven critical role in the knowledge management process. In 1776, Adam Smith also affirmed in "An Inquiry into Nature and Causes of the Wealth of Nations" that productivity and quality can be maximized by investing in the employees' education and learning (Hanaysha, 2016). Corresponding to the same idea, Teece (1998) explained that a knowledge-based strategy could provide increasing returns; therefore, continuously learning fosters the firms' capacity to beat competitors in the long run. The conventional industrial economic model focused on machinery and financial capital. In the recent economic perspective, knowledge has become a primary factor of production (Tzortzaki \& Mihiotis, 2014) which has proven itself especially in the knowledge-intensive services sector (Girma, 2017; Powell, 2003; Sveiby, 1997). Effective management of knowledge of a firm explains as a learning organization (Sinkula, Baker, \& Noordewier, 1997). From a macro perspective, education and skills provide a foundation for learning and human development (N. Hanif \& Arshed, 2016). Using knowledge as a competitive source, organizations develop internal capabilities and skills to manage their R\&D activities (H. Chesbrough, 2003).

While grounding the theoretical model on knowledge management theory, it is indubitable to consider the role of tacit knowledge and its flow. People possess tacit knowledge (Ribeiro, 2013) and structure in mental schemas that may have been evolved through education. People struggle to compete in the job market through investing in quality education \& skills. On the other hand, firms seek to hire workers those are possessing competitive knowledge and skills. Therefore, on one side, knowledge is created, and on the other side, the knowledge is being used to transform the individual into a valuable resource, i.e., an innovator. Therefore, the knowledge management process can be used as a practical approach towards innovation. To create value, open innovation (OI) provides new ideas through embracing external knowledge (H. Chesbrough, 2003). Chesbrough (2004) explained that external resources have a prominent position to create value. The concept of OI has been redefined by H. W. Chesbrough, W. Vanhaverbeke, and J. West (2014) as "a distributed innovation process based on purposively managed knowledge flows across organizational boundaries." However, literature has little cope to discuss the association of knowledge acquisition or creation as a significant antecedent of innovation.

Theoretical development in KBV described innovation dependency on human capital and their ability to respond towards innovative activities. However, their absorption capacity in firms determines the level of utilization within an economy towards the innovation process. New knowledge creation and ideation come from a higher level of education and training (Schmidt, 2005). This process increases the firm's absorption capacity (demand), increasing hiring of more skilled employees. Knowledge acquisition is a learning process within an organization, and the acquisition of external knowledge determines knowledge acquisition. Acquisition originates through associative actions with other organizations, universities, and consulting firms (Gonzalez \& Martins, 2017). On one side, higher education and training work as an efficiency enhancer for sustainable growth and work as knowledge creation ingredients.

\section{Problem Statement and Research Gap}

In literature, little research covers both firms and economic perspectives towards innovation; therefore, this paper will be focusing on the aggregate behavior of firms operating in a country. In developed countries, knowledge does not restrict to regional boundaries, but it flows globally. Therefore, highly human capital 
developed countries often address current challenges through appropriate systematic channels addressing retention or employment of knowledge workforce. In firm-specific research, limited research explains the aggregate role of scholarly society working in firms. The world is full of abundant resources, including knowledge not confined to one country or one region; it implies worldwide. On one side, people in a country are getting an education and acquiring new knowledge and skills; on the other side, they are being hired in organizations and using their knowledge to develop new ideas for innovation.

This deterministic behavior towards the innovation of a society can be explained through the positivist perspective. The knowledge acquisition process is not limited to individuals and organizational learning. Therefore, the ontological dimension, coming to be, of knowledge acquisition at the country level is missing in the literature and only covers the epistemological dimension at the firm level. Further, the relationship between theory and practice implies an epistemological position (Morgan \& Smircich, 1980). KBV talks about the competitive advantage that can be created through intangible resources. These resources are deeply embedded in processes, routines, and the experience of the people. Human capital resources have a critical position to promote innovation. The epistemological position would be KBV of the firm that talks about implicit and explicit knowledge that enables organizations to develop existing knowledge to innovate by acquiring human capital resources. Knowledge resources are being acquired from the external environment. The capacity of organizations to deploy or hire people would be determined as a mechanism through which innovation would be developed.

Knowledge systems in developed countries are more successful in developing human capital than in less developed countries (Hanushek \& Kimko, 2000; Hanushek \& Woessmann, 2008); therefore, the education system in a country fosters skills and knowledge acquisition (Ryan \& Niemiec, 2009). Because of this characteristic, this study will explore the role of knowledge acquisition in developed economies.

This new model is based on a knowledge-based perspective for the long-run growth, whereby innovation plays a significant role in sustainable economic development. Previous studies have focused on FDI, capital goods imports, and technology licensing, which were considered sources of technological knowledge (Cimoli, 2005). The global crisis forced us to rethink existing policies and focus on a knowledge-based economy, especially how individuals and organizations interact and accumulate knowledge (Padilla-Pérez \& Gaudin, 2014). Exports and FDI have not proved to be the robust growth engines they were supposed to be. Second, the unfolding of the 2008-2009 global crisis made it more evident that markets by themselves do not lead to inclusive long-run economic growth and that active public policies are needed (Stiglitz, 2012). Therefore, the previously misdirected focus of researchers has been transferred to knowledge-based factors, and therefore, knowledge acquisition in a country through delivering quality education and developing skills determine as a critical driving force of innovation.

In comparison with knowledge distribution, studies support the positive link between knowledge acquisition from employees or the market with innovation (Cooper, 1979; Li \& Calantone, 1998). Knowledge and skilled employees come from the external environment, and their engagement in industries helps develop capabilities within firms to perform R\&D activities. On the other hand, the literature suggests that implicit knowledge has a limited role in innovation (Abbey \& Dickson, 1983; Moorman \& Miner, 1997).

According to Cohen and Levinthal (1990), absorptive capacity captures a firm's ability to value, assimilate, and apply new knowledge. In acquiring the process of new knowledge, firms focus on a knowledgeable workforce. The notion of knowledge acquisition affirms individuals' capacity to learn and generate new knowledge to transform a firm's capabilities. However, firms need to hire knowledgeable workers to utilize their new knowledge in operations and routines. It is evident from the literature that human capital is a fundamental pillar of knowledge-based companies (Bontis, Dragonetti, Jacobsen, \& Roos, 1999). Knowledge-intensive companies 
relatively employ a high number of knowledgeable workers. The higher the number of people working in an organization, determines higher absorptive capacity. It is an indicator of low unemployment in a country and making sense of optimal human capital utilization. Knowledge acquisition is not something stored in the brain, information systems, or in books (Cook \& Brown, 1999; Gherardi, Nicolini, \& Odella, 1998), but how much the demand for knowledgeable workers has been increased in firms yielding competitive advantage. Knowledge workers make smart action and create new knowledge that ultimately transforms into innovation. Therefore, in this study, absorption capacity - employment is considered to be a mediating variable.

\section{Hypotheses Development}

While encountering a competitive situation in the job market, people try to develop their skills and knowledge to participate in economic activity. Their learning capacity determines through their level of education and related experience. Therefore, knowledge creation, acquiring and transforming foster organizations' capacity to change their behaviors reflected in new insights and ideas (Epstein \& Roy, 1997). Our framework covers the theoretical foundations of the knowledge management perspective, elucidating the role of knowledge creation/absorption in building the capacity to innovate through the mediating role of knowledge absorption capacity.

\section{Research Questions}

The main research questions of this study are:

1. To what extent knowledge acquisition have fostered open innovation?

2. To what extent absorptive capacity enhanced open innovation output?

Literature suggests that efficient implementation and adoption of innovation systems/practices is dependent on relevant formal institutions, i.e., intellectual property rights, technology licensing offices, R\&D labs, academia, innovation centers, and technological incubators (Tödtling \& Trippl, 2005). Economic institutions are defined as "rules of the game" in a society (North, 1990) and determinants of economic growth (Mauro, 1995).

\section{Literature Review}

Researchers have highlighted both organizational performance and sustainable development in the strategic management domain, linked with the firms' strategic orientation. (Cameron \& Whetten, 1983) propagated the dimensionality of business performance on theoretical, empirical, and managerial grounds. The direction of theoretical perspectives under the strategic management firm performance is the ultimate strategic move (Schendel \& Hofer, 1979). Here the first section would cover the role of innovation strategy towards firm performance in competitiveness. Firms' interaction enables firms to determine a required strategy to take a sustainable position in the market.

External knowledge considers being a critical source for a firm's innovativeness (Duysters \& Lokshin, 2011). The firms often require the knowledge that society possesses in education and skills to achieve sustainable competitive advantage. In other words, knowledge acquisition is embedded in the labor force (Christensen \& Drejer, 2005).

The literature on innovation has focused on exploring firms' strategies and their effect on firms' performance in economic and industrial terms. Previous studies highlighted researchers' interest in finding an empirical relationship between innovation strategies and firms' performance (Schroll \& Mild, 2012; West \& Bogers, 2014). However, little research has focused on causal factors of innovation at the macro level, focusing on knowledge, skills, and abruption capacity to hire skilled workers in industries. 
Market compete heavily to get insight information, such as firms learn through interaction and perform actions based on product innovation's available information to exploit or explore markets. Research and development enable firms to determine the need of the external markets by bringing external knowledge within the organizations to respond accordingly. Making the $\mathrm{R} \& \mathrm{D}$ department is a strategic decision. Hiring skilled people to respond to the external environment also strengthen strategic decision.

Many authors empirically investigated that innovation promoting strategies have a strong association with performance. Firms compete and interact in markets through unique strategies and in resultant knowledge and ideas exchange. If a firm absorbs the external knowledge within the internal processes and routines, there would be higher chances to innovate successfully. Many authors highlighted open innovation strategies coupled with inbound and outbound OI (Cheng \& Huizingh, 2014; Hernández-Espallardo, Sánchez-Pérez, \& SegoviaLópez, 2011; Ortiz-de-Urbina-Criado, Montoro-Sánchez, \& Mora-Valentín, 2012), and in this regard several authors confirmed the strategic role of collaboration with various partners including supplier, customers, competitors, and research institutions (Czarnitzki \& Thorwarth, 2012; Un, Cuervo-Cazurra, \& Asakawa, 2010; Vega-Jurado, Gutiérrez-Gracia, \& Fernández-de-Lucio, 2009).

Open innovation activities are divided into two dimensions: firstly, inbound or outside-in open innovation that explains exploration and integration with external knowledge; secondly, outbound or inside-out open innovation that focuses on external avenues of exploitation of technological capabilities for the commercialization of technology (H. Chesbrough, 2003; Chesbrough \& Crowther, 2006). Lundvall and Borrás (2005) emphasized science policies focusing on scientific knowledge, research, research and development laboratories, public research centers. The commercialization of innovation requires technology policies. The outcome of these activities results in economic growth (Verspagen, 1992).

It implies that a firm can collaborate with external organizations (Chesbrough \& Crowther, 2006), such as through the product development process. It is a substitute for internal $R \& D$, which reduces the internal $R \& D$ intensity of a company. It involves customers for product development activities. The outbound open innovation includes external collaboration in product development (Chesbrough, Vanhaverbeke, \& West, 2006) and licenses out technologies to other firms (Henkel, 2006; Van de Vrande, De Jong, Vanhaverbeke, \& De Rochemont, 2009). Outbound innovation focuses on developing ideas within the organization and then commercializing them in external markets. Outbound innovation is the way to develop ideas inside of the organization and commercialized them. This might be through the selective revealing a product to journalists and reviewers or selectively selling the technology or service to customers to get feedback. Therefore, both exploration and exploitation of knowledge resources for innovation activities trigger growth. Thus, investment in technology will increase the capacity of firms to maximize growth and profitability. The overall industry will grow in both ways; therefore, it will affect the overall growth of the industry.

The overall growth of an economy depends upon innovation systems. National innovation systems create competitive advantage and foster economic growth (Nelson \& Rosenberg, 1993) and productivity (Kalim, Arshed, \& Shaheen, 2019). Innovation systems consist of the following: infrastructure stability, and environment, and the nature of the relationship between them (Furman, Porter, \& Stern, 2002). The structure of innovation systems facilitates interaction among small and large firms, public and academic communities. This process allows us to develop and improve technology and innovation.

Government policies have a significant role in promoting innovation activities. Focusing policies on academic institutions (universities) and research centers strengthen innovation systems in a country. Secondly, institutions implement laws, regulations, and policies necessary to supporting innovation systems (Cunningham \& Link, 2016). There is a wide array of policy instruments that governments can implement to strengthen innovation systems. The government uses the following policies to develop innovation systems: public investment, trade 
policies, straightening SME sector, training, education, and development at the regional level (Padilla-Pérez \& Gaudin, 2014).

\section{Knowledge management (KM)}

The KBV states that the individuals possess the knowledge, and they exercise this knowledge; they are the actual owner of this knowledge, which creates value. From a social learning perspective, knowledge is an outcome of learning. Learning takes place through expenditure on health and education. Ultimately, it establishes the optimization of the values of individuals living in a society. They become more productive and efficient. This develops human values and brings competitive advantage and economic growth for the industries (Jashapara, 2004). The learning process would shape in the form of quality of education and skill set of people. The acquired knowledge and skills in a country are required to be absorbed in employment opportunities. This mechanism would impact overall innovation in industries. Knowledge management practices produce intellectual capital that plays their role toward economic growth (Jashapara, 2005).

For policymakers in highly human-developed countries, the recognition of innovation has been widely accepted. While developing human capital, the role of human productivity is witnessed through their role in business growth. For instance, in Central America, policymakers have recognized the importance of science, technology, and innovation toward sustainable economic growth.

\section{Entrepreneurship and Absorptive capacity}

The primary relationship between entrepreneurship and financial performance is diminishing financial returns. Entrepreneurial activities develop the new capacity of knowledge absorption by responding to opportunities. Entrepreneurship enables firms to capitalize on external opportunities innovatively. It develops the absorptive capacity that motivates firms to configure their knowledge-based resources towards the commercialization of activities. The notion of entrepreneurial orientation strategy focuses on creating and pursuing new market opportunities (Lumpkin \& Dess, 1996).

As discussed earlier, knowledge absorption capacity determines through the potential of organization routines and processes to acquire, absorb and exploit knowledge (Zahra \& George, 2002). For organization growth, the strategic posture of entrepreneurial orientation directs towards new opportunities. From EO perspective, it covers three dimensions: 1) innovativeness; it helps to use knowledge-based resources towards innovation, 2) proactiveness; it means identification of external opportunities, 3) risk-taking; it deals with uncertainty but helps to be a pioneer in new offering (Miller, 2011). Lastly, entrepreneurship channelizes in between firm performance and absorptive capacity by the commercialization of new knowledge.

\section{KM \& Innovation}

H. W. Chesbrough (2003) and Segarra-Blasco, Garcia-Quevedo, and Teruel-Carrizosa (2008) emphasized the importance of external knowledge and its role towards internal R\&D activities. Education, skilled and trained people are required within organizations to support internal R\&D activities. They pointed out that new ideas and knowledge should be responded to avoid approaching new opportunities spontaneously. Otherwise, they will be lost. Therefore, firms can create new ways of value creation and maximize growth by combining external knowledge into internal R\&D activities. The hiring of more knowledge or skill-based labor works as a mediating role in between knowledge creation and open innovation. According to Chesbrough (2007), he elucidated that the growing division of labor is an essential driving force towards innovation. A survey-based study on 120 SMEs of Indonesia by Gunawan, Jacob, and Duysters (2016) pointed out that cluster ties between industries moderate the knowledge acquisition and innovation relationship. Based on these ideas, the following hypothesis will be tested.

H1: Knowledge acquisition will positively affect innovation 


\section{Knowledge acquisition \& Absorptive capacity}

Earlier technological knowledge sources include importing capital goods, FDI and technology licensing (Cimoli, 2005). However, now, knowledge-based resources are considered to be more critical towards technological knowledge. Limited research has been done on linking the economic aspect of firms toward knowledge and skills available in the market and its causal relationship with innovation. Absorptive capacity would determine firms' ability to operate in a country towards acquiring knowledge that resides outside and develops new products and services. Absorptive capacity can be determined at two levels: firstly, potential absorptive capacity deals with the assimilation of knowledge, and secondly, realized absorptive capacity discusses the exploitation of knowledge. (Zahra \& George, 2002). Lane and Lubatkin (1998) made the case that a firm might not learn equally from each external firm. It depends upon the capacity of individuals to learn quickly. The absorptive capacity of firms in a country will be higher if firms are prone to more employability of the skilled workforce.

Individuals' learning and development through acquiring knowledge make them more competitive. In competitive economies, people focus on education to make themselves more competitive in the job market. Their tacit knowledge is valuable for organizations competing on technological grounds. For these organizations, therefore, it is inevitable to lose capacity in giving jobs to help workers. Rothwell and Dodgson (1991) confirmed, firms should access knowledge from outside, including technicians, technological specialists, and engineers. Absorptive capacity develops within firms through hiring knowledge inputs: tertiary education, quality of math and science education, internet access in schools, availably of research and training services, quality of the educational system, quality of management schools, and extent of staff training. Knowledge input through knowledge and skills in a society facilities firms to hire people accompanied with competitive skills, therefore more employable opportunities would be generated in a country, and higher absorption capacity through employment channelize businesses towards innovation. Thus, the following hypothesis will be validated.

H2: Knowledge acquisition will positively affect Absorptive capacity

\section{Absorptive capacity and innovation}

The third hypothesis addresses the mediating role of absorptive capacity channelizing between knowledge acquisition and innovation. Firms need knowledge and information from both external and internal sources to develop a culture of innovative performance. Bringing external knowledge inside the organization and using it within processes and routines depends upon absorptive capacity (Zahra \& George, 2002). Knowledge acquisition from external sources is necessary to achieve a competitive advantage. The limited capacity to absorb new knowledge restricts firms' ability to absorb new knowledge (Szulanski, 1996). Therefore, it is inevitable for firms to maximize absorptive capacity to craft new opportunities by acquiring new knowledge. External knowledge is available equally but might not bring equal benefits to every organization. In technological advancement, it all depends upon the current absorptive capacity of processes and routines. Therefore, organizations have to invest in labor force skills and their knowledge to achieve technological advancement (Keller, 1996).

According to Wong, Ho, and Autio (2005), changing nature of absorptive capacity has a significant influence on innovation. Innovation can be influenced through two possible reasons: firstly, targeting high skilled labor turns out to be more productive, and they could be directed towards innovative activities. Secondly, organizational, entrepreneurial activities could be streamlined using the absorptive capacity of skilled labor because they could easily turn into new opportunities.

H4: Absorptive capacity will mediate between Knowledge acquisition and Innovation 


\section{Conceptual model}

Figure 1 elaborates the role of absorptive capacity as a mediating variable between knowledge acquisition and innovation. KBV explains the proposed association among mentioned variables. In a country, the education system determines the capability of individuals to perform in organizations. More knowledgeable people become part of the organizations, more competition tends to emerge, and more innovation will be seen. It turns out to be the competitive advantage of firms that can absorb knowledge by hiring competitive people while operating in highly developed human capital countries. In case of high demand for knowledge workers in an economy, more patents ideas would be registered in a country.

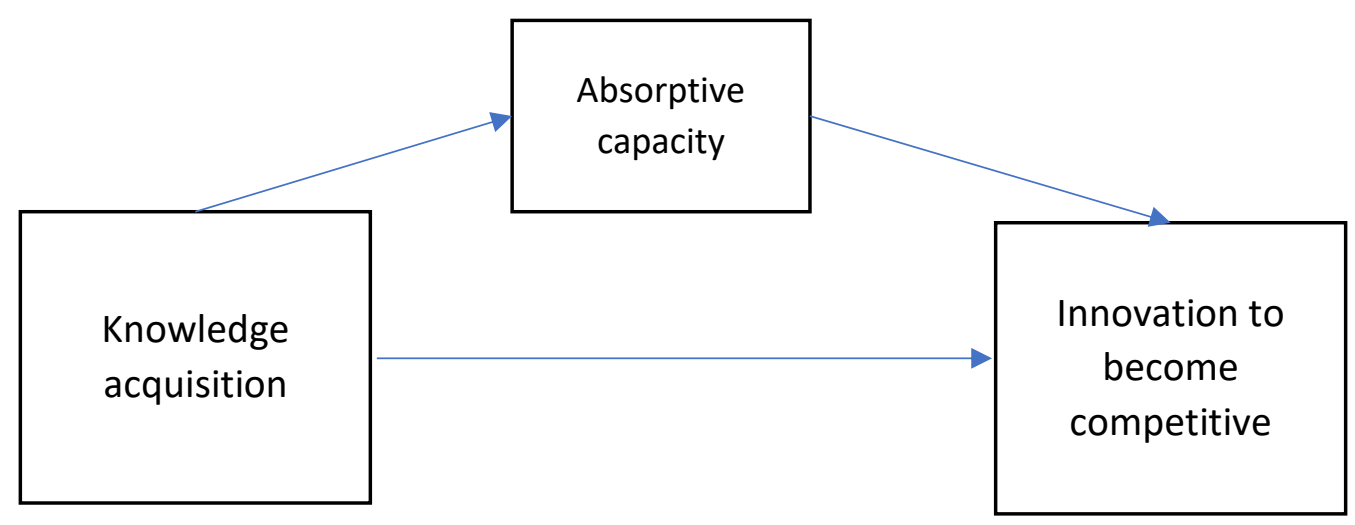

Figure 1 - Mediation model of Innovation

\section{Methods}

\section{Data Framework and Sample}

This study has constituted the panel data framework using country aggregate data (as it is deemed acceptable by (Kleiner, 2011) to minimize the multicollinearity among the independent variables. Further, this approach has several benefits, such as increased efficiency because of the bigger sample size, incorporation of knowledge spillover effect, and country-wise heterogeneity (N. Arshed, Anwar, Kousar, \& Samra, 2018). The panel data model's use helps to study the differences in nation-wide organizational behavior and norms and explore the time evolution because of experience and exposure to new challenges. The Positivist paradigm is used in this study, which measures the social phenomena by selecting a large sample and careful selection of statistical tests (Creswell, 2009).

Data of variables (shown in Table 1) are drawn from World Bank and World Economic Forum. Since the emergence of a knowledge-based economy, High HDI countries have focused on developing human capital to stay in the competition. Earlier in the literature, the transaction cost theory model was operative in which cost minimization was the firm's strategy. Therefore, the cost can be cut to an extent as discussed knowledge-based resources are core for creating competitive advantage. Quality of education, quality of science education, training, and tertiary education, play an essential role towards human capital development and consider as a knowledge acquisition ingredient. 
Innovation in a country consists of factors covering both government and industry contribution: Quality of scientific research institutions, company spending on R\&D, availability of scientists and engineers, PCT patent applications, Government procurement of advanced technology products. Determinants of innovation are indicators of country competitiveness that have a strong association with knowledge acquisition.

This study has collected secondary data from 48 developed countries as per World Bank criteria to fulfill the research objectives, as they are a suitable candidate for knowledge economies. The data is taken from 20082017. The description of the variables is provided below.

Table 1 - Variable Descriptions

\begin{tabular}{|c|c|c|}
\hline Indicator (Symbol) & Description & Source \\
\hline Innovation Index (INNO) & Index Score (1-7) & (WEF, 2018) \\
\hline Knowledge Acquisition Index (KA) & Index Score (1-7) & (WEF, 2018) \\
\hline \multirow[t]{2}{*}{$\begin{array}{l}\text { Absorptive Capacity, Unemployment } \\
\text { (UNEM) }\end{array}$} & $\begin{array}{l}\text { Unemployment } \% \text { of Total labor force } \\
\text { (modeled ILO estimate) }\end{array}$ & (WDI, 2018) \\
\hline & Control Variables & \\
\hline Development Expenditures (DEV) & $\begin{array}{l}\text { Education and Health expenditures (\% of } \\
\text { GDP) }\end{array}$ & (WDI, 2018) \\
\hline Institutions Index (INST) & Index Score (1-7) & (WEF, 2018) \\
\hline Infrastructure Index (INF) & Index Score (1-7) & (WEF, 2018) \\
\hline Trade Openness (OPEN) & Total trade $(\%$ of GDP) & (WDI, 2018) \\
\hline New Business Density (NBD) & New business / population & $\begin{array}{l}\text { (Business, } \\
\text { 2018) }\end{array}$ \\
\hline
\end{tabular}

The dependent variable is the index of innovation proposed by the Global Competitiveness Index (WEF, 2018); this includes the following indicators: the capacity for innovation, quality of scientific research institutes, company spending on $\mathrm{R} \& \mathrm{D}$, university-Industry collaboration in $\mathrm{R} \& \mathrm{D}$, Gov't procurement of advanced tech products, availability of scientists and engineers and PCT patent applications / million population. Spending money on R\&D generates new ideas that turn into innovation (Capon et al., 1992). Therefore, R\&D activities become more competitive.

While the index of knowledge acquisition index includes gross secondary enrollment, gross tertiary enrollment, quality of education system, quality of math and science education, quality of management schools, internet access in schools, availability of research and training services, and extent of staff training, knowledge and skills development is only possible through quality of education, Existing empirical literature recognizes human capital created through investments in education and the development of skill as one of the most significant determinants of economic growth (R. Barro \& Sala-i-Martin, 1995; R. J. Barro, 1991; Schultz, 1963). The control variable of institutions index comprises several indicators. These indicators include property rights, intellectual property protection, diversion of public funds, public trust in politicians, irregular payments and bribes, judicial independence, favoritism in decisions of government officials, the efficiency of government spending, wastefulness of government spending, burden of government regulation, the efficiency of the legal framework in settling disputes, efficiency of the legal framework in challenging regulations, transparency of government policymaking, business costs of terrorism, business costs of crime and violence, organized crime, reliability of police services, ethical behavior of firms, the strength of auditing and reporting standards, efficacy of corporate boards, protection of minority shareholders' interests and strength of investor protection. For efficient innovation systems, formal institutions have core importance that consists of institutes of licensing new technological ideas, innovation centers, academic institutes (Tödtling \& Trippl, 2005). 
Lastly, the index of infrastructure is comprised of quality of overall infrastructure, quality of roads, quality of railroad infrastructure, quality of port infrastructure, quality of air transport infrastructure, availability of airline seat km/week, quality of electricity supply, mobile telephone subscription / 100 population, and fixed telephone lines/100 population. Furman et al. (2002) found that innovation infrastructure and environment determine the strength of the innovation system.

\section{Estimation Equation}

Knowledge acquisition influences business innovation directly and indirectly through the channel of absorptive capacity. Hayes (2017) provides the foundation for the mediation model, which can help in identifying the direct (knowledge acquisition to innovation) and indirect channel (knowledge acquisition to innovation via absorptive capacity) of effects. Similar model was used by (Leal-Rodriguez, Roldan, \& Ariza-Montes, 2014; S. H. Liao, Fei, \& Chen, 2007).

$\mathrm{Y}_{\mathrm{it}}=\alpha_{0}+\mathrm{cX}_{\mathrm{it}}+\mathrm{dZ} \mathrm{Z}_{\mathrm{it}}+\varepsilon_{\mathrm{it}}$

$Y_{i t}=\alpha_{1}+c_{1} X_{i t}+b_{i t}+d Z_{i t}+\varepsilon_{y i t}$

$\mathrm{M}_{\mathrm{it}}=\alpha_{2}+\mathrm{a} \mathrm{X}_{\mathrm{it}}+\mathrm{d}^{\prime} \mathrm{Z}^{\prime}{ }_{\mathrm{it}}+\varepsilon_{\mathrm{mit}}$

Herec $=$ Total effect

$c_{1}=$ Direct effect

$\mathrm{ab}=$ Indirect effect

$\mathrm{Y}=$ Dependent variable $=$ Innovation $(\mathrm{INNO})$

$\mathrm{X}=$ Independent variable $=$ Knowledge Acquisition $(\mathrm{KA})$

$\mathrm{M}=$ Mediator $=$ Absorptive Capacity $(\mathrm{UNEM})$

Z \& Z' = Control variablesEstimation Approach

Since the data sets are not mesokurtic, there are some differences among the countries used in the sample. This apparent non-homogeneity calls for panel data-based estimation models, which accounts for the heterogeneous differences and knowledge spillovers (Ramadani et al., 2017) among the countries by calculating countryspecific standard errors of the slope coefficients (Greene, 2012). This model is known as Panel Feasible Generalized Least Square model. The advantage of this approach is that it can modify the matrix of country and variable standard errors, to control for heteroscedasticity, cross-sectional autocorrelation, and time-series autocorrelation (N Arshed \& Kalim, 2020; N Arshed, Rauf, \& Bukhari, 2021; N Hanif, Arshed, \& Aziz, 2020; Hassan, Bukhari, \& Arshed, 2019).

\section{Results}

\section{Descriptive Statistics}

Table 2 shows that none of the variables had a standard deviation higher than their mean value, confirming that they are not overdispersed, indicating the similarity of variables between countries and their movements in time. Further significant normality test (Jarque \& Bera, 1987) confirms that all the variables are non-normal in their current nature. This indicates two things; first, the skewness is not zero. However, according to the central limit theorem (Lind, Marchal, \& Wathen, 2012), the large sample size makes regression estimates asymptotic normal. 
Table 2 - Data Descriptive

\begin{tabular}{cccccc}
\hline Variable & Mean & Std. Dev. & Skewness & Kurtosis & Normality Prob. \\
\hline INNO & 4.22 & 0.86 & 0.22 & 1.73 & 0.00 \\
UNEM & 7.66 & 4.63 & 1.57 & 6.04 & 0.00 \\
KA & 5.16 & 0.51 & 0.06 & 2.08 & 0.00 \\
OPEN & 117.7 & 83.65 & 2.01 & 6.89 & 0.00 \\
NBD & 6.46 & 6.27 & 1.78 & 6.25 & 0.00 \\
DEV & 9.89 & 3.75 & -0.29 & 2.15 & 0.00 \\
INST & 4.79 & 0.86 & -0.29 & 1.97 & 0.00 \\
INF & 5.17 & 0.83 & -0.43 & 2.81 & 0.00 \\
\hline
\end{tabular}

Figure 2 provides a scatterplot to present the graphical association between knowledge acquisition and innovation, where it can see that an increase in knowledge acquisition is positively associated with innovation. Empirically it is confirmed that higher investment in knowledge acquisition leads to higher technology level (Eicher, 1996). Knowledge motivates individuals to learn continuously to improve their skills (Orlikowski, 2002). Their learning behavior enables them to remain engaged with the organization. Similarly, Figure 2 shows

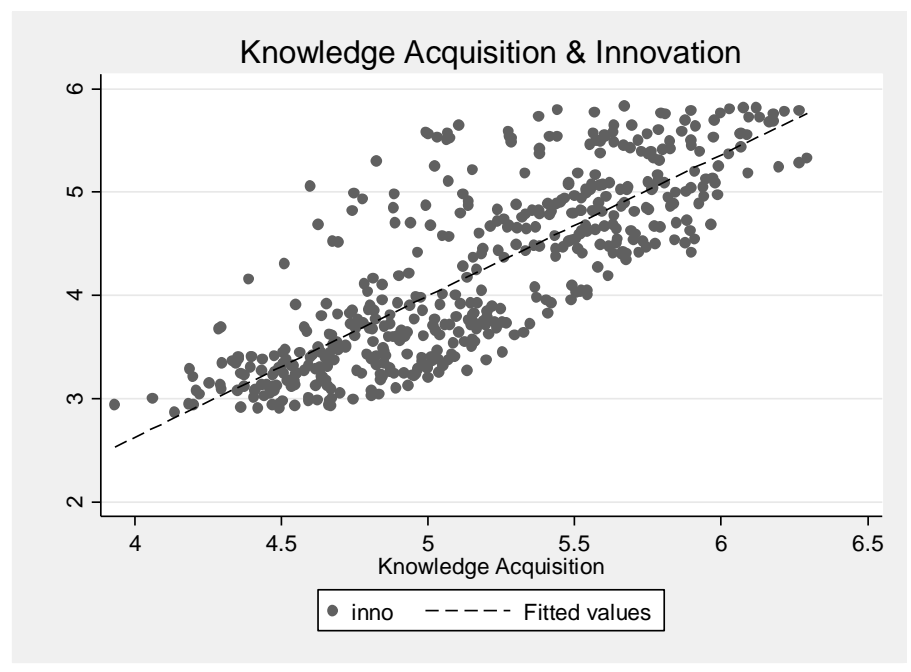

Figure 2 - Scatter plot of knowledge acquisition and innovation 


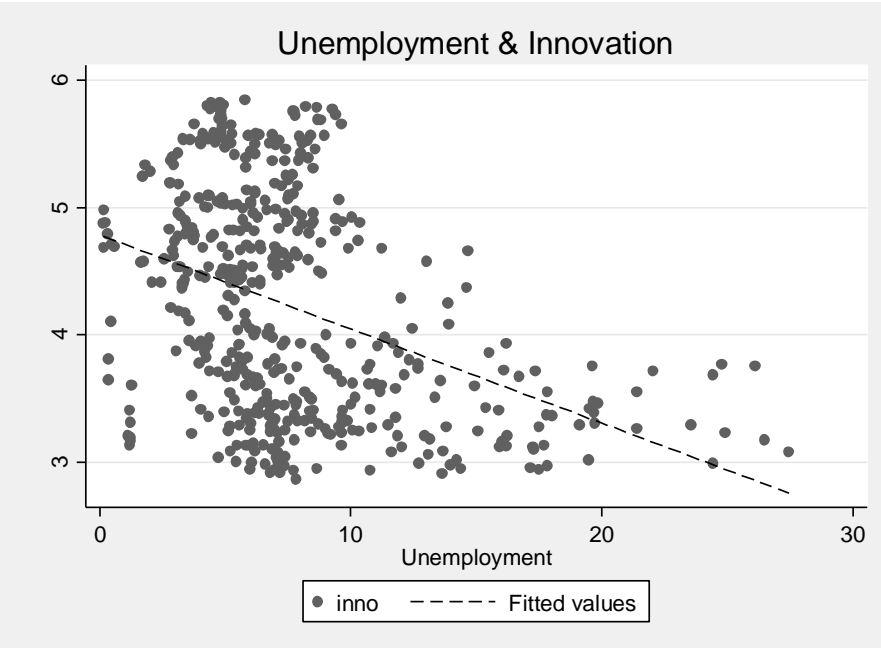

Figure 4 - Scatter plot of unemployment and innovation

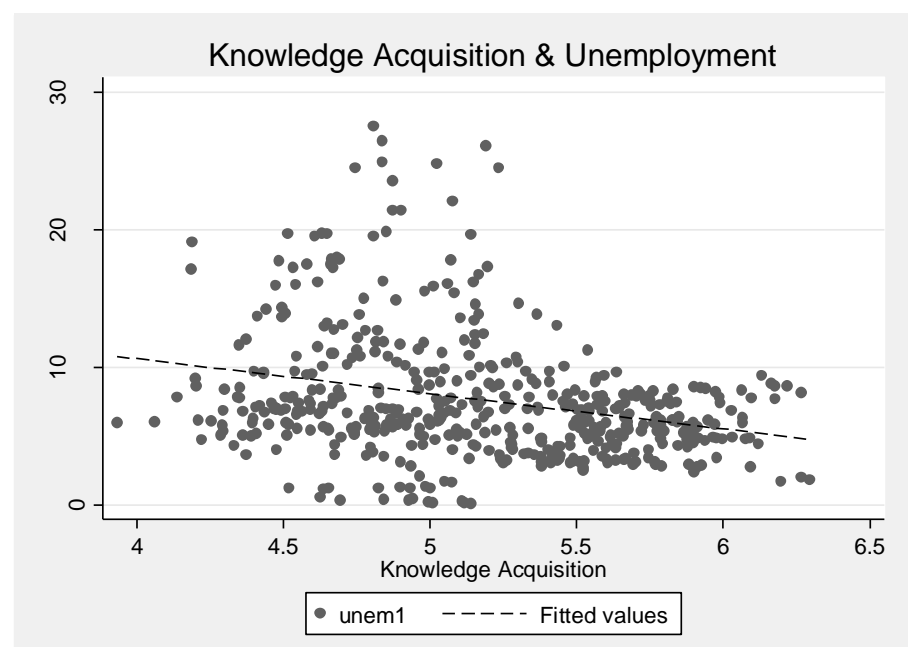

Figure 3 - Scatter plot of knowledge acquisition and unemployment

that unemployment being an inverse proxy of absorptive capacity has a negative association with innovation, indicating that knowledgeable resources increase the business's capacity to pursue innovation.

Figure 4 confirms the negative association between knowledge acquisition and the unemployment rate in the economy. Mincer (1991) highlighted that an increase in labor resource skill increases its demand because of an increase in its expected capacity to innovate.

\section{Estimation Results}

Three equations (eq. 1, 2, 3) are estimated to estimate the mediator model. The significant Wald test (in Table 3) shows that all the models are fit. While exploring the controlling factors, the increase in the development expenditures, institutions, and infrastructure significantly increases the innovations in the economy. Innovation depends upon geographical conditioning besides individual firms' efforts towards innovation. Geographical and institutional infrastructure development mobilizes technical resources from one place to another, which works as an essential factor in the innovation process (Feldman \& Florida, 1994). Once the infrastructure is built, it becomes favorable for firms to experiment with the distinct strategy to get a competitive advantage; similar is the case for good institutes as they help reduce barriers (Segarra-Blasco et al., 2008). 
Table 3 - Regression Estimates

\begin{tabular}{lccc}
\hline \multicolumn{4}{c}{ Panel FGLS Model Estimates } \\
\hline Dep. Var. & INNO & INNO & UNEM \\
Indep. Var. & Coef. (Prob.) & Coef. (Prob.) & Coef. (Prob.) \\
KA & $0.73(0.00)$ & $0.71(0.00)$ & $-1.86(0.00)$ \\
UNEM & & $-0.02(0.00)$ & \\
DEV & $0.02(0.00)$ & $0.03(0.00)$ & \\
INST & $0.23(0.00)$ & $0.15(0.00)$ & \\
INF & $0.23(0.00)$ & $0.26(0.00)$ & $-0.07(0.00)$ \\
NBD & & & $-0.01(0.00)$ \\
OPEN & & $-1.65(0.00)$ & $18.03(0.00)$ \\
Constant & $-2.09(0.00)$ & 385 & 398 \\
Sample & 385 & $5964(0.00)$ & $173.510 .00)$ \\
Wald & $6226(0.00)$ & & 10 \\
\hline
\end{tabular}

While analyzing equation 3 (in Table 3), an increase in trade openness and entrepreneurship increases the absorptive capacity (by decreasing unemployment). Globalization generates employment opportunities that absorb access to labor from the market. Secondly, a segment of individuals who start up their businesses (based on opportunity or necessity) has some new innovative ideas. They assimilated into an economy and played their part toward innovation activities. Self-employment reduces unemployment in a country (Audretsch, Carree, \& Thurik, 2001).

Here, a $1 \%$ increase in the knowledge acquisition index increases by $0.73 \%$ in the innovation index and a $1.86 \%$ increase in absorptive capacity leading to acceptance of alternative hypotheses (H1 and H2). This overall total effect is comprised of a direct effect whereby a $1 \%$ increase in the knowledge acquisition leads to directly increasing the innovation by $0.71 \%$ while indirectly increasing innovation by $0.037 \%$ via the absorptive capacity channel1. S.-H. Liao, Wu, Hu, and Tsui (2010) Molina-Morales et al. (2014) also found a statistically significant relationship between knowledge acquisition and innovation. The procedure to test the significance of the mediation effect is proposed by (Baron \& Kenny, 1986; MacKinnon, Warsi, \& Dwyer, 1995). Here significant test values of Sobel (1982), Goodman (1960), and Aroian (1944) tests shown in Table 4 confirm the presence of mediation effect.

Table 4 - Mediation Test

\begin{tabular}{lccc}
\hline & Test Statistic & Std. Error. & P-value \\
\hline Sobel Test & 5.71 & 0.01 & 0.00 \\
Aroian Test & 5.69 & 0.01 & 0.00 \\
Goodman Test & 5.73 & 0.01 & 0.00 \\
\hline
\end{tabular}

\section{Discussions}

The results pointed out the empirical outcomes of the theoretical model using extensive panel data. This study started with the hypothesis that knowledge acquisition could create a competitive advantage for the firms by expanding the absorptive capacity. The negative effect of knowledge on unemployment and the negative effect of unemployment on innovation confirmed this hypothesis.

\footnotetext{
${ }^{1}$ Since the coefficient value of $\mathrm{a}$ and $\mathrm{b}$ in equation 2 and 3 are significant hence it can be expected that the cross product is also significant.
} 


\section{Conclusion}

Conventional wisdom states that organizations hold, protect, and intend to increase their technological and innovation knowledge. Without considering the macro-economic environment, organizations could not assess a complete picture of factors affecting their innovation capacity. Intangible resources (idiosyncratic resources) under RBV can create a competitive advantage. These resources have specific characteristics: valuable, rare, inimitable, and non-substitutable (Barney, 1991), which would lead to a competitive advantage. The same applied to the economic perspective, where expenditure on knowledge and skills develops the resources that can be competitive. So, the possessed knowledge of the people cannot be partible; instead, it grows in the long run. Education increases human capital and, in turn, increases their absorptive capacity, innovation, and economic growth via business competitiveness. This development process of knowledge over time shapes innovation - engineers, quality research, and economic growth. Knowledge growth has not been limited to firms, but it goes beyond the country to a global level. The current challenges faced by high human development countries have been observed to design and implement a systematic policies framework toward sustainable industrial and economic growth. Conventionally, FDI, import of capital goods, and licensing technology considered technological knowledge sources (Cimoli, Ferraz, \& Primi, 2005).

However, knowledge acquisition such as knowledge and skills sources have significant importance towards innovation. Therefore, a knowledge-based economy (KBE) drives the economy through using knowledge, production, and processes. In contrast, the production-based economy only focuses on growth accelerators such as factors of production and technology, but it ignores the function that relates to knowledge management.

This study concludes with important policy implications needed for developing a systematic policy mechanism for the innovation process. The policy should be focusing on a sufficient budget on quality of education and infrastructure development. This approach provides a platform and develops the capacity of individuals to learn and grow. Secondly, their sustainability by deploying into the job market consider to be challenging but would work as long as the knowledge acquisition process is competitive. Thirdly, innovation models need to be reassessed and redirect by focusing on human capital development that covers a couple of things such as health, food, and education. Healthy nations would be more mentally strong, more competitive to learning and innovation, and valuable toward overall economic growth. Researchers may check other intermediary variables such as talent and health to see the association between knowledge acquisition and innovation as the results are limited within the model.

Funding: This research received no external funding

Acknowledgments: We acknowledge the School of Business and Economics' faculty members by providing ideas and relevant studies.

Conflicts of Interest: The authors declare no conflict of interest.

\section{References}

Abbey, A., \& Dickson, J. W. (1983). R\&D work climate and innovation in semiconductors. Academy of Management Journal, 26(2), 362-368.

Anderson, N., \& West, M. A. (1996). The Team Climate Inventory: Development of the TCI and its applications in teambuilding for innovativeness. European Journal of work and organizational psychology, 5(1), 53-66.

Aroian, L. A. (1944). Some Methods for the Evaluation of a Sum. Journal of the American Statistical Association, 39(228), 511-515.

Arshed, N., Anwar, A., Kousar, N., \& Samra, B. (2018). Education Enrollment Level and Income Inequality: A Case of SAARC Economies. Social Indicators Research, 140(1), 1211-1224. 
Arshed, N., \& Kalim, R. (2020). Modelling demand and supply of Islamic banking deposits. International Journal of Finance \& Economics.

Arshed, N., Rauf, R., \& Bukhari, S. (2021). Empirical Contribution of Human Capital in Entrepreneurship. Global Business Review, 0972150920976702.

Audretsch, D. B., Carree, M. A., \& Thurik, A. R. (2001). Does entrepreneurship reduce unemployment? : Tinbergen Institute discussion paper.

Barney, J. (1991). Firm resources and sustained competitive advantage. Journal of management, 17(1), 99-120.

Baron, R. M., \& Kenny, D. A. (1986). The moderator-mediator variable distinction in social psychological research: Conceptual, strategic, and statistical considerations. Journal of personality and social psychology, 51(6), 1173.

Barro, R., \& Sala-i-Martin, X. (1995). Economic growth, New York, McGrow-Hill: Inc.

Barro, R. J. (1991). Economic growth in a cross section of countries. The quarterly journal of economics, 106(2), 407-443.

Bontis, N., Dragonetti, N. C., Jacobsen, K., \& Roos, G. (1999). The knowledge toolbox:: A review of the tools available to measure and manage intangible resources. European management journal, 17(4), 391 402.

Business, D. (2018). Doing Business Report: World Bank.

Cameron, K. S., \& Whetten, D. A. (1983). Models of the organizational life cycle: Applications to higher education. The Review of Higher Education, 6(4), 269-299.

Capon, N., Farley, J. U., Lehmann, D. R., \& Hulbert, J. M. (1992). Profiles of product innovators among large US manufacturers. Management Science, 38(2), 157-169.

Cheng, C. C., \& Huizingh, E. K. (2014). When is open innovation beneficial? The role of strategic orientation. Journal of Product Innovation Management, 31(6), 1235-1253.

Chesbrough, H. (2003). Open innovation: Boston: Harvard Business School Press.

Chesbrough, H. (2004). Managing open innovation. Research-Technology Management, 47(1), 23-26.

Chesbrough, H. (2007). Business model innovation: it's not just about technology anymore. Strategy \& leadership, 35(6), 12-17.

Chesbrough, H., \& Crowther, A. K. (2006). Beyond high tech: early adopters of open innovation in other industries. R\&d Management, 36(3), 229-236.

Chesbrough, H., Vanhaverbeke, W., \& West, J. (2006). Open innovation: Researching a new paradigm: Oxford University Press on Demand.

Chesbrough, H., Vanhaverbeke, W., \& West, J. (2014). New frontiers in open innovation: Oup Oxford.

Chesbrough, H. W. (2003). Open innovation: The new imperative for creating and profiting from technology: Harvard Business Press.

Chesbrough, H. W., Vanhaverbeke, W., \& West, J. (2014). New Frontiers in Open Innovation: Oxford University Press.

Christensen, J., \& Drejer, I. (2005). The strategic importance of location: Location decisions and the effects of firm location on innovation and knowledge acquisition. European Planning Studies, 13(6), 807-814.

Cimoli, M. (2005). Science and technology policies in open economies: The case of Latin America and the Caribbean (Vol. 165): United Nations Publications.

Cimoli, M., Ferraz, J. C., \& Primi, A. (2005). Science and technology policies in open economies: The case of Latin America and the Caribbean.

Cohen, W. M., \& Levinthal, D. A. (1990). Absorptive capacity: A new prespective on learning and innovaton. Administrative Science Quarterly, 129-152.

Cook, S. D., \& Brown, J. S. (1999). Bridging epistemologies: The generative dance between organizational knowledge and organizational knowing. Organization science, 10(4), 381-400. 
Cooper, R. G. (1979). The dimensions of industrial new product success and failure. The Journal of Marketing, 93-103.

Creswell, J. W. (2009). Mapping the field of mixed methods research: SAGE publications Sage CA: Los Angeles, CA.

Cunningham, J. A., \& Link, A. N. (2016). Exploring the effectiveness of research and innovation policies among European Union countries. International Entrepreneurship and Management Journal, 12(2), 415-425.

Czarnitzki, D., \& Thorwarth, S. (2012). Productivity effects of basic research in low-tech and high-tech industries. Research Policy, 41(9), 1555-1564.

Duysters, G., \& Lokshin, B. (2011). Determinants of alliance portfolio complexity and its effect on innovative performance of companies. Journal of Product Innovation Management, 28(4), 570-585.

Eicher, T. S. (1996). Interaction between endogenous human capital and technological change. The Review of Economic Studies, 63(1), 127-144.

Epstein, M. J., \& Roy, M. J. (1997). Using ISO 14000 for improved organizational learning and environmental management. Environmental Quality Management, 7(1), 21-30.

Feldman, M. P., \& Florida, R. (1994). The geographic sources of innovation: technological infrastructure and product innovation in the United States. Annals of the association of American Geographers, 84(2), 210-229.

Freeman, C., \& Soete, L. (1997). The economics of industrial innovation: Psychology Press.

Furman, J. L., Porter, M. E., \& Stern, S. (2002). The determinants of national innovative capacity. Research Policy, 31(6), 899-933.

Gherardi, S., Nicolini, D., \& Odella, F. (1998). Toward a social understanding of how people learn in organizations: The notion of situated curriculum. Management learning, 29(3), 273-297.

Girma, B. (2017). Intellectual capital efficiency and its impact on financial performances of Ethiopian commercial banks. Research Journal of Finance and Accounting, 8(8), 17-31.

Gonzalez, R. V. D., \& Martins, M. F. (2017). Knowledge Management Process: a theoretical-conceptual research. Gestão \& Produção, 24(2), 248-265.

Goodman, L. A. (1960). On the exact variance of products. Journal of the American Statistical Association, 55(292), 708-713.

Greene, W. H. (2012). Econometric analysis (6th ed.). NJ: Prentice Hall.

Gunawan, T., Jacob, J., \& Duysters, G. (2016). Network ties and entrepreneurial orientation: Innovative performance of SMEs in a developing country. International Entrepreneurship and Management Journal, 12(2), 575-599.

Hanaysha, J. (2016). Examining the effects of employee empowerment, teamwork, and employee training on organizational commitment. Procedia-Social and Behavioral Sciences, 229, 298-306.

Hanif, N., \& Arshed, N. (2016). Relationship between school education and economic growth: SAARC countries. International Journal of Economics and Financial Issues, 6(1), 294-300.

Hanif, N., Arshed, N., \& Aziz, O. (2020). On interaction of the energy: Human capital Kuznets curve? A case for technology innovation. Environment, Development and Sustainability, 22(8), 7559-7586.

Hanushek, E. A., \& Kimko, D. D. (2000). Schooling, labor-force quality, and the growth of nations. American economic review, 90(5), 1184-1208.

Hanushek, E. A., \& Woessmann, L. (2008). The role of cognitive skills in economic development. Journal of Economic Literature, 46(3), 607-668.

Hassan, M. S., Bukhari, S., \& Arshed, N. (2019). Competitiveness, governance and globalization: What matters for poverty alleviation? Environment, Development and Sustainability(1-28). doi: 10.1007/s10668019-00355-y

Hayes, A. F. (2017). Introduction to mediation, moderation, and conditional process analysis: A regression-based approach: Guilford publications. 
Henkel, J. (2006). Selective revealing in open innovation processes: The case of embedded Linux. Research Policy, 35(7), 953-969.

Hernández-Espallardo, M., Sánchez-Pérez, M., \& Segovia-López, C. (2011). Exploitation-and explorationbased innovations: the role of knowledge in inter-firm relationships with distributors. Technovation, 31(5-6), 203-215.

Jarque, C. M., \& Bera, A. K. (1987). A test for normality of observations and regression residuals. International Statistical Review / Revue Internationale de Statistique, 55(2), 163-172.

Jashapara, A. (2004). Knowledge management: An integrated approach: Pearson Education.

Jashapara, A. (2005). The emerging discourse of knowledge management: a new dawn for information science research? Journal of information science, 31(2), 136-148.

Kalim, R., Arshed, N., \& Shaheen, S. (2019). Does competitiveness moderate inclusive growth: a panel study of low-income countries. Competitiveness Review: An International Business Journal.

Keller, W. (1996). Absorptive capacity: On the creation and acquisition of technology in development. Journal of Development Economics, 49(1), 199-227.

Kleiner, G. (2011). The Resource-Based View and the System Organization of Economy. Russian management journal, 9(3), 3-28.

Kuhlmann, S., Shapira, P., \& Smits, R. (2010). Introduction. A systemic perspective: the innovation policy dance. The theory and practice of innovation policy. An international research bandbook, 1-22.

Lane, P. J., \& Lubatkin, M. (1998). Relative absorptive capacity and interorganizational learning. Strategic management journal, 19(5), 461-477.

Leal-Rodriguez, A. L., Roldan, J. L., \& Ariza-Montes, J. A. (2014). From potential absorptive capacity to innovation outcomes in project teams: The conditional mediating role of the realized absorptive capacity in a realational learning context. International Journal of Project Management, 32(6), 894-907.

Li, T., \& Calantone, R. J. (1998). The impact of market knowledge competence on new product advantage: conceptualization and empirical examination. The Journal of Marketing, 13-29.

Liao, S.-H., Wu, C.-C., Hu, D.-C., \& Tsui, K.-A. (2010). Relationships between knowledge acquisition, absorptive capacity and innovation capability: an empirical study on Taiwan's financial and manufacturing industries. Journal of information science, 36(1), 19-35.

Liao, S. H., Fei, W. C., \& Chen, C. C. (2007). Knowledge sharing, absorptive capacity, and innovation capability: an empirical study of Taiwan's knowlegde-intensive industries. Journal of Information Science, 33(3), 340-359.

Lind, D. A., Marchal, W. G., \& Wathen, S. A. (2012). Statistical techniques in business \& economics: New York, NY: McGraw-Hill/Irwin.

Lumpkin, G. T., \& Dess, G. G. (1996). Clarifying the entrepreneurial orientation construct and linking it to performance. Academy of management review, 21(1), 135-172.

Lundvall, B.-Å., \& Borrás, S. (2005). Science, technology, and innovation policy Oxford handbook of innovation (pp. 599-631): Oxford University Press.

MacKinnon, D. P., Warsi, G., \& Dwyer, J. H. (1995). A simulation study of mediated effect measures. Multivariate Behavioral Research, 30(1), 41-62.

Martín-de-Castro, G., Delgado-Verde, M., López-Sáez, P., \& Navas-López, J. E. (2011). Towards 'an intellectual capital-based view of the firm': origins and nature. Journal of business ethics, 98(4), 649-662.

Mauro, P. (1995). Corruption and growth. The quarterly journal of economics, 110(3), 681-712.

Miller, D. (2011). Miller (1983) revisited: A reflection on EO research and some suggestions for the future. Entrepreneurship Theory and Practice, 35(5), 873-894.

Mincer, J. (1991). Education and unemployment: National Bureau of Economic Research. 
Molina-Morales, F. X., García-Villaverde, P. M., \& Parra-Requena, G. (2014). Geographical and cognitive proximity effects on innovation performance in SMEs: a way through knowledge acquisition. International Entrepreneurship and Management Journal, 10(2), 231-251.

Moorman, C., \& Miner, A. S. (1997). The impact of organizational memory on new product performance and creativity. Journal of marketing research, 91-106.

Morgan, G., \& Smircich, L. (1980). The case for qualitative research. Academy of management review, 5(4), 491 500.

Nelson, R. R., \& Rosenberg, N. (1993). Technical innovation and national systems. National innovation systems: A comparative analysis, 322.

Orlikowski, W. J. (2002). Knowing in practice: Enacting a collective capability in distributed organizing. Organization science, 13(3), 249-273.

Ortiz-de-Urbina-Criado, M., Montoro-Sánchez, Á., \& Mora-Valentín, E. M. (2012). Do firm’s sector and size influence on the degree of inbound open innovation? International Journal of Transitions and Innovation Systems, 2(2), 169-193.

Padilla-Pérez, R., \& Gaudin, Y. (2014). Science, technology and innovation policies in small and developing economies: The case of Central America. Research Policy, 43(4), 749-759.

Porter, M. E. (1980). Industry structure and competitive strategy: Keys to profitability. Financial analysts journal, 36(4), 30-41.

Powell, C. (2003). The Delphi technique: myths and realities. Journal of advanced nursing, 41(4), 376-382.

Ramadani, V., Abazi-Alili, H., Dana, L.-P., Rexhepi, G., \& Ibraimi, S. (2017). The impact of knowledge spillovers and innovation on firm-performance: findings from the Balkans countries. International Entrepreneurship and Management Journal, 13(1), 299-325.

Randhawa, K., Wilden, R., \& Hohberger, J. (2016). A bibliometric review of open innovation: Setting a research agenda. Journal of Product Innovation Management, 33(6), 750-772.

Ribeiro, R. (2013). Tacit knowledge management. Phenomenology and the cognitive sciences, 12(2), 337-366.

Rothwell, R., \& Dodgson, M. (1991). External linkages and innovation in small and medium-sized enterprises. Red Management, 21(2), 125-138.

Rutten, R., \& Boekema, F. (2005). Innovation, policy and economic growth: Theory and cases: Taylor \& Francis.

Ryan, R. M., \& Niemiec, C. P. (2009). Self-determination theory in schools of education: Can an empirically supported framework also be critical and liberating? School Field, 7(2), 263-272.

Salampasis, D., \& Mention, A.-L. (2017). Open Innovation: Unveiling the Power of the Human Element. World Scientific Publishing Co. Pte. Ltd.

Schendel, D., \& Hofer, C. W. (1979). Strategic management: A new view of business policy and planning: Little, Brown. Schmidt, T. (2005). What determines absorptive capacity. Paper presented at the DRUID summer conference.

Schroll, A., \& Mild, A. (2012). A critical review of empirical research on open innovation adoption. Journal für Betriebswirtschaft, 62(2), 85-118.

Schultz, T. W. (1963). The economic value of education: Columbia University Press.

Segarra-Blasco, A., Garcia-Quevedo, J., \& Teruel-Carrizosa, M. (2008). Barriers to innovation and public policy in Catalonia. International Entrepreneurship and Management Journal, 4(4), 431-451.

Sinkula, J. M., Baker, W. E., \& Noordewier, T. (1997). A framework for market-based organizational learning: Linking values, knowledge, and behavior. Journal of the academy of Marketing Science, 25(4), 305.

Sobel, M. E. (1982). Asymptotic confidence intervals for indirect effects in structural equation models. Sociological methodology, 13, 290-312.

Solow, R. M. (1956). A contribution to the theory of economic growth. The quarterly journal of economics, 70(1), 65-94. 
Song, M., Podoynitsyna, K., Van Der Bij, H., \& Halman, J. I. M. (2008). Success factors in new ventures: A meta-analysis. Journal of product innovation management, 25(1), 7-27.

Stiglitz, J. E. (2012). The price of inequality: How today's divided society endangers our future: WW Norton \& Company.

Sveiby, K. E. (1997). The new organizational wealth: Managing \& measuring knowledge-based assets: Berrett-Koehler Publishers.

Szulanski, G. (1996). Exploring internal stickiness: Impediments to the transfer of best practice within the firm. Strategic management journal, 17(S2), 27-43.

Teece, D. J. (1998). Capturing value from knowledge assets: The new economy, markets for know-how, and intangible assets. California management review, 40(3), 55-79.

Tödtling, F., \& Trippl, M. (2005). One size fits all?: Towards a differentiated regional innovation policy approach. Research Policy, 34(8), 1203-1219.

Tzortzaki, A. M., \& Mihiotis, A. (2014). A review of knowledge management theory and future directions. Knowledge and Process Management, 21(1), 29-41.

Un, C. A., Cuervo-Cazurra, A., \& Asakawa, K. (2010). R\&D collaborations and product innovation. Journal of Product Innovation Management, 27(5), 673-689.

Van de Vrande, V., De Jong, J. P., Vanhaverbeke, W., \& De Rochemont, M. (2009). Open innovation in SMEs: Trends, motives and management challenges. Technovation, 29(6-7), 423-437.

Vega-Jurado, J., Gutiérrez-Gracia, A., \& Fernández-de-Lucio, I. (2009). Does external knowledge sourcing matter for innovation? Evidence from the Spanish manufacturing industry. Industrial and corporate change, 18(4), 637-670.

Verspagen, B. (1992). Endogenous innovation in neoclassical growth models: a survey. Journal of Macroeconomics, 14(4), 631-662.

WDI. (2018). World Development Indicators. World Bank Database.

WEF. (2018). Global Competitiveness Index: World Economic Forum.

West, J., \& Bogers, M. (2014). Leveraging external sources of innovation: a review of research on open innovation. Journal of Product Innovation Management, 31(4), 814-831.

Wirtz, B. W., Schilke, O., \& Ullrich, S. (2010). Strategic development of business models: implications of the Web 2.0 for creating value on the internet. Long range planning, 43(2-3), 272-290.

Wong, P. K., Ho, Y. P., \& Autio, E. (2005). Entrepreneurship, innovation and economic growth: Evidence from GEM data. Small Business Economics, 24(3), 335-350.

Zahra, S. A., \& George, G. (2002). Absorptive capacity: A review, reconceptualization, and extension. Academy of management review, 27(2), 185-203. 